\title{
Long-Term Steady-State Dry Boreal Forest in the Face of Disturbance
}

\author{
Christopher Carcaillet, ${ }^{1,2 *} \odot$ Mireille Desponts, ${ }^{3}$ Vincent Robin,,${ }^{4}$ and \\ Yves Bergeron ${ }^{5}$
}

\begin{abstract}
${ }^{1}$ Laboratory for Ecology of Natural and Anthropised Hydrosystems (UMR 5023 CNRS ENTPE UCBL), Université Lyon 1, 69622 Villeurbanne, France; ${ }^{2}$ Paris Sciences and Lettres Université (PSL), École Pratique des Hautes Études (EPHE), Paris, France; ${ }^{3}$ Ministère des Forêts, de la Faune et des Parcs, Gouvernement du Québec, Direction de la recherche forestière, 2700 rue Einstein, Québec, Québec G1P 3W8, Canada; ${ }^{4}$ Interdisciplinary Laboratory for Continental Environments (LIEC), University of Lorraine, CNRS, Campus Bridoux, Rue du Général Delestraint, 57070 Metz, France; ${ }^{5}$ Institut de recherche sur les forêts, Université du Québec en Abitibi-

Témiscamingue, 445 boulevard de l'Université, Rouyn-Noranda, Québec J9X 5E4, Canada
\end{abstract}

\begin{abstract}
We used bioproxies from paleosoils buried within two aeolian dunes to test hypotheses concerning the origin of dry sandy boreal forests in Canada. These forests are dominated today by Pinus banksiana Lamb. One hypothesis is that too frequent Holocene stand-replacing fires would have transformed the original vegetation through extirpation of susceptible species to fire in water stress habitat. Alternatively, the ecosystem would have not changed since the dunes stabilized enough to support forest establishment. The vegetation composition and richness were determined by identification of charcoal and macroremains and radiocarbon dating for the chronology. Both sites revealed a similar history covering 6400 years. Half
\end{abstract}

Received 18 March 2019; accepted 13 October 2019;

published online 30 October 2019

Electronic supplementary material: The online version of this article (https://doi.org/10.1007/s10021-019-00455-w) contains supplementary material, which is available to authorized users.

Authors Contributions Y.B. and C.C. led the study; M.D. carried out the sampling, the sedimentological analyses and the macroremain identifications; V.R. carried out the charcoal identifications; C.C. analyzed the data and wrote the first draft; all authors approved the final version of the manuscript.

Plain language summary: Boreal forest (plant composition, richness) growing on sandy soil remained stable despite fires since the dune inception 6400 years ago. These dry sandy forests are resilient and resistant to stressors. Changes in fire and climate during last millennia did not change the steady state of vegetation, which appears adapted to the ecosystem on sandy soil.

*Corresponding author; e-mail: christopher.carcaillet@ephe.psl.eu of the charcoal layers were less than 2500 years old in both sites, indicating that they had been subjected to the same fire history. Data indicated a stable plant composition and richness, although the percentage of Pinus decreased slightly over 4000 years (decreasing rate $1 \%$ per century). The fungus Cenococcum geophilum was consistently present, with a stochastic abundance. The vegetation grew under natural fire conditions and soil dryness since 6000 years. The ecosystem was probably not stressed by late-Holocene fires or climate changes, as the multi-millennial steady state reveals a resistant and resilient ecosystem.

Key words: Perturbation; Resilience; Resistance; Fire; Paleoecology; Macrofossil; Quebec. 


\section{INTRODUCTION}

In boreal regions, the long-term compositional origin of forests on dry soils has important conservation implications (for example, regarding biodiversity, carbon, soil erosion) because of industrial tree exploitation and other global changes that can threaten these boreal 'snow' forests (Moen and others 2014; Gauthier and others 2015). Boreal forests are generally fire prone. If we can determine the origin of such fire-prone ecosystems, that is, progressive transformation versus initial spontaneous emergence, we may also understand the ecosystem linkage between community and disturbance and, in particular, whether a change in disturbance regime could result in a transformation of community or whether a steady state would be maintained for a long time whatever the disturbance regimes. These hypotheses question the resilience of the system. Two long-term scenarios can be considered (Figure 1). First, we hypothesized that the initial postglacial ecosystem was not appropriate for stand-replacing fires, and that frequent fires have progressively altered the ecosystem by limiting or increasing its functionalities (Figure 1D, E), for instance, the plant recruitment due to effects on seed bed properties or on seed productivity of trees (too short fire interval according to tree reproductive maturity, for example, Viglas and others 2013) or by progressive decrease in biogeochemical mechanisms (McLauchlan and others 2014), promoting the most fire-adaptable species over species less resilient or resistant. The unknown initial system would have progressively or abruptly moved to an alternative steady state or basin of attraction (Scheffer and others 2001), based on the interaction between the disturbance regime and other environmental stressors that promote transformation of ecosystems (McLauchlan and others 2014; Oliver and others 2015). Second, we hypothesized that the ecosystem was functionally resilient to frequent fires as soon as the habitat was colonized after deglaciation without intermediate states (Figure $1 \mathrm{~A}-\mathrm{C})$, whatever climatic changes and soil maturation processes that drive the main natural chronic or rapid environmental changes in boreal habitats.

In North America, snow forests on dry soils are dominated by Pinus banksiana Lamb., from the Northwest Territories and Alberta in the west, to Nova Scotia in the east, Wisconsin-Michigan in the south and the Canadian forest-tundra transition in the north. Fire pattern could have controlled some long-term variation in vegetation composition under climatic change (Genries and others 2012; Lynch and others 2014), and modern populations might have arisen from the fragmentation of populations at the landscape scale since the middle Holocene approximately 6000 years ago (Payette and others 2017). However, it is unclear whether the modern ecosystem-P. banksiana, forests on dry soil-is the legacy of past processes (disturbances, climate) that have progressively reformed the initial system by rarefaction or extirpation of susceptible species, or whether the modern dominant tree species appeared immediately after deglaciation and have been sustained dominant until today in a steady state. Indeed, it has been shown that afforestation of pines might have occurred without lag soon after the deglaciation in northeastern North America (Blarquez and Aleman 2016). In the North American boreal shield, other species in this system, potentially susceptible to fire and soil dryness, include black spruce (Picea mariana Mill. BSP) and white spruce (Picea glauca (Moench) Voss.), respectively, balsam fir [Abies balsamea (L.) Mill.] and eastern white cedar (Thuja occidentalis L.) (for example, Visnadi and others 2019). Broadleaved boreal trees (for example, Betula papyrifera Marshall or Populus tremuloides Michx.) are not expected to abound on sandy soils because they require too much water.

Ecosystems with dry sandy soil dominated by $P$. banksiana are currently sustained by frequent fires (for example, Lavoie and Sirois 1998; Le Goff and Sirois 2004; Tweiten and others 2015), and fire occurrences are sustained by high $P$. banksiana density (for example, Héon and others 2014), making these forests fire-prone ecosystems that are seemingly resilient (Day and others 2017; Hart and others 2018). The positive feedback results in intimate interactions between the fire and ecosystem processes. Indeed, $P$. banksiana presents response traits to the fire regime (Gauthier and others 1996; Radeloff and others 2004; de Groot and others 2004; Briand and others 2015) and controls the fire spread by effect traits (Fonda 2001). Furthermore, $P$. banksiana dominant ecosystems are also often associated with rocky outcrops, fluvioglacial deposits or aeolian dunes (Schmidt and Carmean 1988) covered by ground lichens (Cladina type), all of which are substrata that stimulate fire spread as a result of soil dryness and fuel quality. These ecosystems are generally nutrient-poor and dependent on mycorrhizal fungi that are stressed by ground lichens (Pacé and others 2019a, 2019b) either through allelopathy (Brown and Mikola 1974) or other soil biogeochemical processes (Sedia 


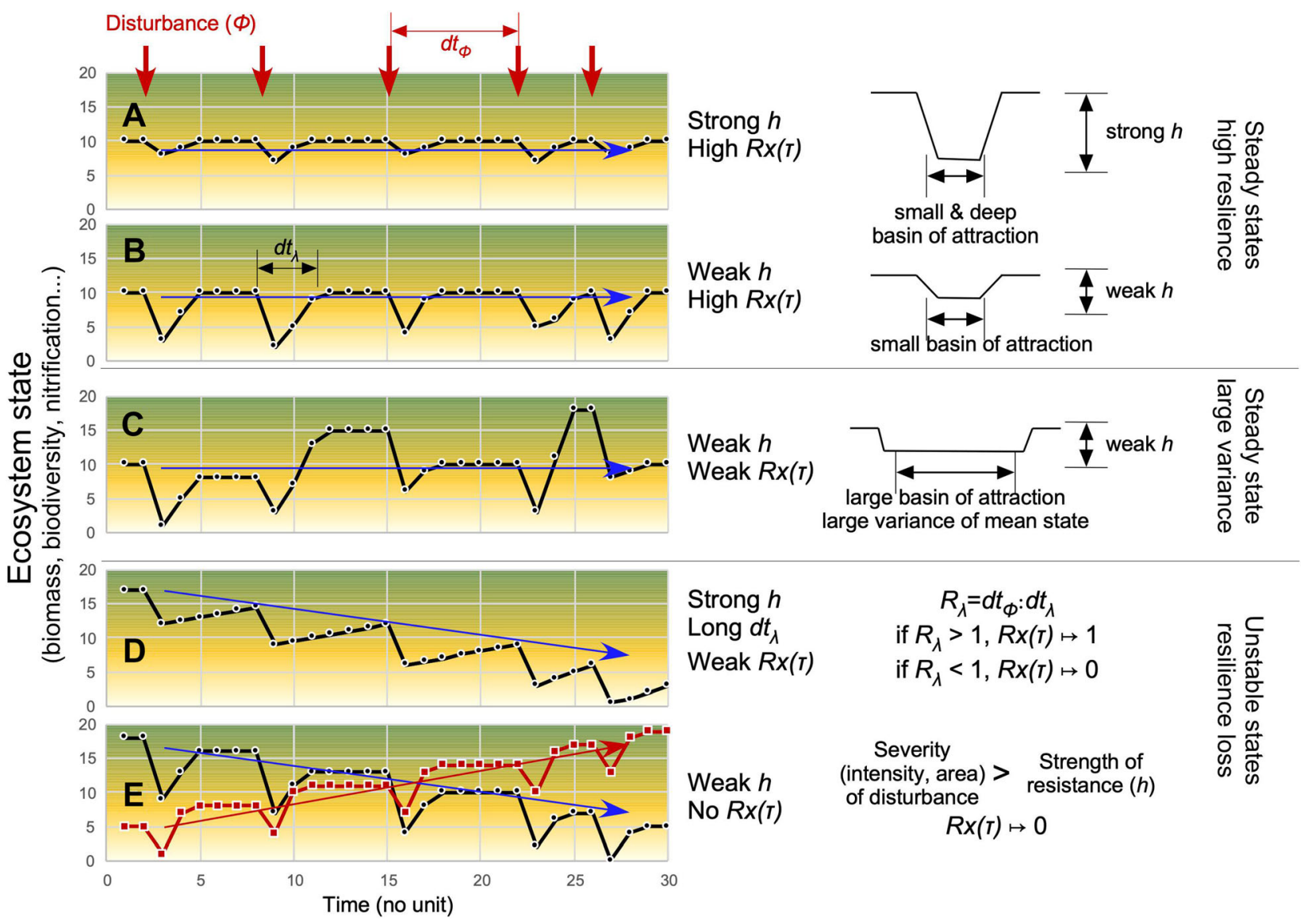

Figure 1. Conceptual diagram of the cumulative effects of a certain disturbance (red arrows, $\varphi$ ), on the temporal stability of a regularly disturbed system; in this workout, the type of disturbance (for example, fire), its intensity (energy given off; Johnson 1992) and its frequency (event numbers per time unit) are constants. (A) Over time, the resistance of the ecosystem $(h)$ is strong enough to secure the recovery and thus the full temporal autocorrelation of ecosystem state $[R x(\tau)=1]$ measured by comparison between state values before and after the disturbance (biomass, biodiversity, interaction networks, biogeochemistry, etc.); in this case, the resilience $(\lambda)$ is maximal and the system is long-term steady. (B) The resistance $(h)$ is weak, but the resilience is strong because the recovery rate is strong and rapid enough thus allowing a full autocorrelation. (C) The resistance $(h)$ and the autocorrelation $[R x(\tau)<1]$ are weak, but the basin of attraction is large enough to guarantee the long-term stability of the system (metastable); the high variance of the system is due to hazards of disturbance parameters (season, severity, area) or of post-recovery features (diaspore abundances, weather, interactions with other disturbances, etc.), which control processes (biogeochemistry, productivity) and biodiversity (species traits, demography, biotic interactions, etc.); the large basin of attraction (variance) can be a strength to respond to stress and disturbances and display to high eco-diversity, including internal state of maturation within the large basin of attraction (Müller and others 2016). (D) The ecosystem is unstable because the resilience ratio $\left(R_{\lambda}\right)$ between the disturbance interval $\left(\mathrm{d} t_{\Phi}\right)$ and the recovery time $\left(\mathrm{d} t_{\lambda}\right)$ does not guarantee anymore the conservation of the ecosystem functionalities and thus of states $[R x(\tau) \mapsto 0]$. Over time, the system changes progressively of attraction basin following staircase dynamics. (E, black) The ecosystem is unstable, and its value decreases because of the strength of the disturbance (intensity, extent) largely above the resistance or recovery potential of the system (resilience disequilibrium) affecting its functionalities; (E, red) the instability of the system outcomes from higher value after each disturbance by increasing stock or availability of nutrients resulting a progressive augmentation of ecosystem state values; this trajectory was well conceptualized by McLauchlan and others (2014). Both staircase dynamics (black or red) result a change in attraction basin following a monotonic multi-secular trajectory. The terminology and definitions of resilience terms are provided in Supporting Information (Text S1, Figure S1).

and Ehrenfeld 2006). Precisely, ground lichens reduce the nutrient availability, notably phosphorus and base cations and also release leachates that affect the pine seedling growth, whereas with moss cover on same substratum, the growth of pine seedling is stimulated by fungal development that improves nutrient uptake for plant through mycorrhizal association (Pacé and others 2019a, b). 
Further, with ground lichens, the diversity and abundance of mycorrhizal fungi are lower, probably explaining the depleted nutrition by plants (Pacé and others 2019a, b). These forests are often characterized by even-aged pine canopies, with post-fire tree seedling density and understory composition linked to burn rate or fire severity. When the interval between successive stand-replacing fires is short, young stands dominated by serotinous $P$. banksiana are susceptible to natural regeneration failure due to the time required to produce a seed supply deemed adequate to regenerate a stand, thereby leading to a decline in productive forest cover (Pacé and others 2019b). Very severe fire can burn cones and limit regeneration (Pinno and others 2013), whereas low fire severity on the ground may decrease good seed beds as seedlings need an access to mineral soil to survive drought (Greene and others 2007). Burning of all organic matter by very severe fire can, however, impair stand productivity. However, multi-aged $P$. banksiana communities with scattered Picea mariana and intermingled cover of ground lichen and bryophytes (Figure 2) can be found when fire intervals are long or fire intensity is low (Smirnova and others 2008). In such weakly disturbed forests with ground mosses (Figure 2), the regeneration and growth rate of $P$. banksiana is improved, probably due to a more intense and diverse mycorrhizal process facilitating pine nutrition (Pacé and others $2019 a, b)$.

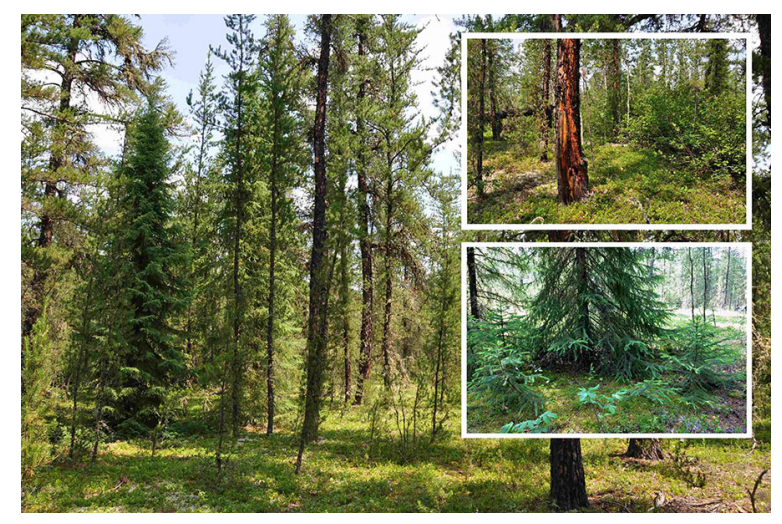

Figure 2. (left) Old-growing boreal forest (multi-aged) on dry sandy soils dominated by jack pine, Pinus banksiana, with intermingled understory of ground lichen and feathermoss, covered by Vaccinium vitis-idaea and presence of Hudsonia tomentosa on bareground soil surface; the tree community includes scattered Betula papyrifera and Picea mariana (left side of the picture) showing vegetative propagation by layering; (top right) detail on layering of P. mariana; (low right) fire scar on trunk of Pinus banksiana, and tall shrub of Alnus viridis photograph credits: Chris Carcaillet.
Here, we thus test the hypothesis that the modern P. banksiana dry soil ecosystem has arisen from initial mixed communities present in the study area since the deglaciation (Picea $\times \mathrm{Pi}_{\text {- }}$ nus $\times$ Abies $\times$ Thuja $\times$ Betula $\times$ Populus; Liu 1990; Richard 1995; Carcaillet and others 2001), from which the species most susceptible to dryness (Picea mariana, P. glauca, Abies balsamea, Thuja occidentalis, Pinus strobus (L.), Betula papyrifera) would have been progressively extirpated as a cumulative result of fires on biogeochemical processes, plant traits or trophic networks, whatever their intensity or their severity (Figure 1D, E). Because P. banksiana promote fire, the fire frequency would have increased over time after the inception of the forest (positive feedbacks). Alternatively, P. banksiana would have been the dominant species as soon as the dune ecosystem was established during the postglacial period, and the fire regime has remained stable as a result of the pine-fire interactions, thus offsetting the role of climate changes on the plant composition or fire regime (Figure $1 \mathrm{~A}-\mathrm{C}$ ). Evidences for the first hypothesis abound in the literature where changes in vegetation and fires occurred during the Holocene progressively (for example, Carcaillet and others 2010; Couillard and others 2018) or abruptly (for example, Jasinski and Payette 2005) moving ecosystems from steady states to another, eventually with intermediate states.

The long-term origin of a forest can be assessed using paleoecological methods. Here, to reach a high spatially accurate analysis of past vegetation and fire, in the absence of peat hollows or very small ponds (few 0.01-0.1 ha) within dunes, we analyzed stratified paleosoils buried in thick dunes (Matthews and Seppälä 2014). This approach is highly spatially accurate although records are very discreet in time and not continuous. Botanical identification of soil charcoal combined with radiocarbon measurements allowed reconstruction of past burned woody vegetation (for example, Robin and others 2013), and subfossil plant macroremains (Birks and Birks 2000) were used to reconstruct past stands of unburnt vegetation (Supporting information S2 on taphonomy of soil/dune charcoal, plant and fungus macroremains).

\section{Materials AND Methods}

\section{Study Area}

The study was conducted in Abitibi, western Quebec (Canada; Figure 3A), about $300 \mathrm{~km}$ south of James Bay, near the Ontario border in the 'north- 
ern clay belt.' This natural region, covering a large area in Ontario and Quebec, comprises a wide plain of the central Canadian shield where main wet and mesic soils overly clay deposited by the proglacial Lake Ojibway (Veillette 1994). The proglacial lake drained abruptly when the residual ice sheet collapsed, allowing a northward outflow to the Hudson Bay, about 8200 calibrated years before present, hereafter 'cal $\mathrm{BP}^{\prime}$ (Barber and others 1999). Theoretically, dunes could thus not have accumulated before about $8200 \mathrm{cal} \mathrm{BP}$. The Abitibi topography is a rolling landscape covered by clayed soils intersected by fluvioglacial deposits (eskers, moraines, sand cover). The Abitibi plains have been wind eroded for 8000 years and have developed parabolic aeolian dunes on clay deposits of the proglacial Lake Ojibway (Figure 3B). During relatively stable periods, woody vegetation grew on these dunes, producing soils (phase of biostasy). Fires then burned the woody vegetation, resulting in charred particles of wood, cones, needles, seeds, etc., which were later covered by sandy deposits during new active aeolian periods (rhexistasy). Such processes have produced paleosoils stratified in thick sandy deposits. They have been well studied in North America and Europe (for example, Filion 1984; Seppälä 1995). Several fires can occur before the burial of paleosoils containing charcoal from these accumulated fires. This type of sandy deposits represents an important source of paleoecological information in dry boreal areas where or when lake sediments or peat is rare (for example, Bélanger and others 2014; Matthews and Seppälä 2014).

\section{Study sites}

Two aeolian dunes were excavated manually with shovels close to the small locality of Villemontel, located (site hereafter named 'Villemontel'; Figure $3 \mathrm{C}, 48.6977^{\circ} \mathrm{N}-78.3630^{\circ} \mathrm{W}$ ) and the nearby Lake Lunette (hereafter 'Lunette'; Figure 3B, $\left.48.7991^{\circ} \mathrm{N}-78.3886^{\circ} \mathrm{W}\right)$. These dunes are situated on the Lake Berry esker, which is about $150 \mathrm{~km}$ long. This esker has been transgressed and eroded by the proglacial Lake Ojibway, resulting in sandy paleobeaches (Allard 1974). This sand occurs at the origin of the parabolic dunes (Figure 3B), notably the Villemontel dune, which are on the summit of the Lake Berry esker. The Lac Lunette dune corresponds to a wide forest area interrupted by dunes about $1.2 \mathrm{~km}$ west of an esker (Figure 3B). Both dunes are about $3 \mathrm{~m}$ thick. At both sites, at the sampling time, the modern forests were dominated by $P$. banksiana approximately 70 years old in Villemontel and 50 years old in Lunette (Table 1), with scattered P. mariana, Betula papyrifera and Populus tremuloides. The canopies were at about $20 \mathrm{~m}$ at Villemontel with a tree density of $25-40 \%$ and about $10 \mathrm{~m}$ in Lunette with a density greater than $80 \%$ (Table 1). The understory is dominated by Kalmia angustifolia L., with Vaccinium L. spp., Hudsonia tomentosa Nutt. and other forbs and herbs, and lichens (Cladonia P. Brown sp.) and mosses (Polytrichum piliferum Hedw.). Both dunes are situated in a transition zone between mixed (southern) and closed-crown (northern) coniferous boreal forests. In 2010, the forest was partly clearcut on the site of Villemontel (Figure 3C).

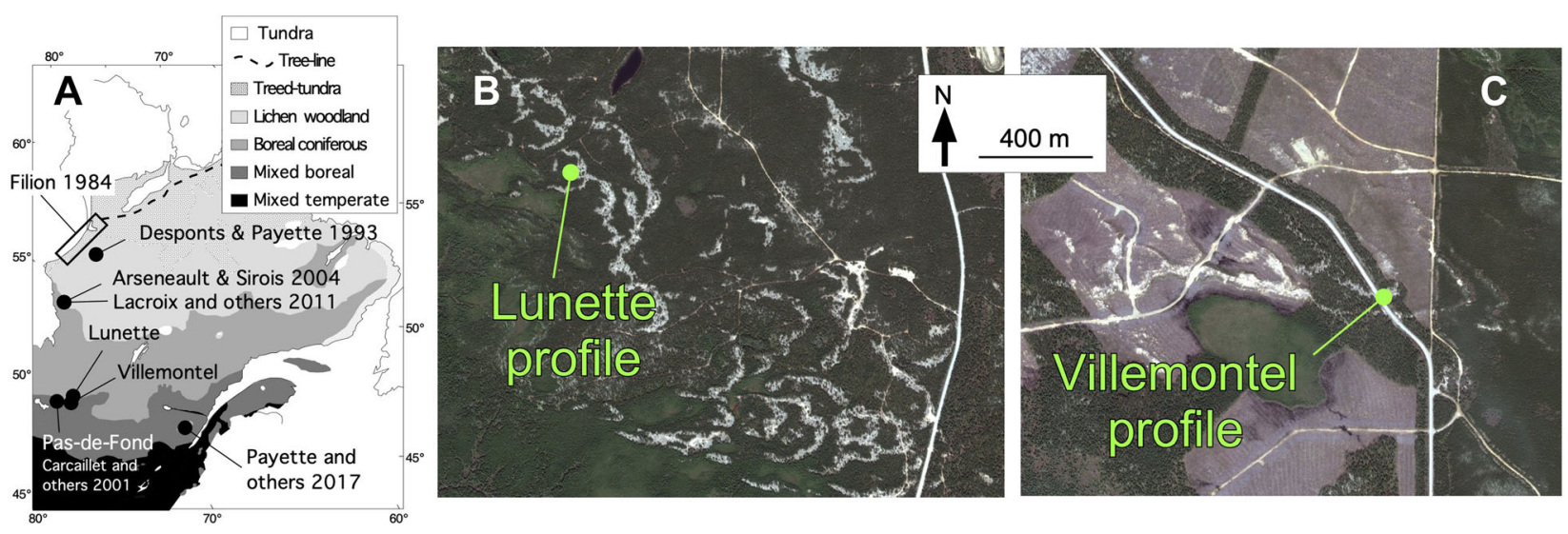

Figure 3. (A) Vegetation map of eastern Canada, with indications of the present study sites (Lunette, Villemontel) and main studies or sites mentioned in the text, which contribute to illustrate the Holocene history of Pinus banksiana forests or fire history in context of dry soils ecosystems. (B) Aerial view of the dune field of Lunette, showing the undisturbed parabolic shape of dunes (light-gray) covered by Pinus banksiana forests. (C) At Villemontel, the forest has been cut and wood harvested probably in 2010, excepted along the main road (Image Landsat/Copernicus 2011; (CDigitalGlobe 2019). 
Table 1. Provincial (Québec) forest inventory data for both study sites

\begin{tabular}{|c|c|c|c|c|c|c|}
\hline \multirow[t]{2}{*}{$\begin{array}{l}\text { Date of satellite im- } \\
\text { age }\end{array}$} & \multicolumn{3}{|c|}{$\begin{array}{l}\text { Lunette } 48.7991^{\circ} \mathrm{N}-78.3886^{\circ} \mathrm{W} \\
(333 \mathrm{~m})\end{array}$} & \multicolumn{3}{|c|}{ Villemontel $48.6977^{\circ} \mathrm{N}-78.3630^{\circ} \mathrm{W}(339 \mathrm{~m})$} \\
\hline & $\begin{array}{l}\text { Stand } \\
\text { age }\end{array}$ & $\begin{array}{l}\text { Tree } \\
\text { density }\end{array}$ & $\begin{array}{l}\text { Tree } \\
\text { height }\end{array}$ & $\begin{array}{l}\text { Stand age } \\
\text { (years) }\end{array}$ & $\begin{array}{l}\text { Tree density } \\
\text { (years) }\end{array}$ & $\begin{array}{l}\text { Tree height } \\
(\mathrm{m})\end{array}$ \\
\hline 1972 & Burned & - & - & 40 & $60-80$ & $12-17$ \\
\hline 1983 & 10 years & $40-60 \%$ & $4-7 \mathrm{~m}$ & 50 & $40-60$ & $12-17$ \\
\hline 2002 & 30 years & $60-80 \%$ & $7-12 \mathrm{~m}$ & 70 & $60-80$ & $17-22$ \\
\hline 2007 & 50 years & $>80 \%$ & $7-12 \mathrm{~m}$ & 70 & $25-40$ & $17-22$ \\
\hline
\end{tabular}

Source: http://mffp.gouv.qc.ca/les-forets/inventaire-ecoforestier/. All the data are interpretations estimated from the satellite images.

\section{Dune Sampling and Chronology}

The profiles were dug until the base was reached at Villemontel, and until no traces of pedogenesis activity were observed at Lunette. The clay deposit was never met both in Lunette and Villemontel. The dune profiles were cleared for a width of $1 \mathrm{~m}$. Both sedimentary sequences comprised sandy material interrupted by charred organic accumulations. Each organic layer corresponded to a past stabilized soil that had burned at least once. The granulometry was measured in laboratory along the profiles.

Eight charred layers were dated at Villemontel and five at Lunette (Table 2). They were dated by ${ }^{14} \mathrm{C}$ measurements at the GEOTOP center (Université du Québec à Montréal, Canada; measurements labeled UQ) and at the Centre d'Études Nordiques (Université Laval, Canada; UL). A bulk of charcoal or plant macroremains (Table 2) was preferred to a single remain in order to reduce the dating risk of older material reworked by blowing to the dune. The ${ }^{14} \mathrm{C}$ measurements were calibrated with CALIB 7.0.4 (Stuiver and Reimer 1993) using the IntCall3 dataset (Reimer and others 2013). The CALIB tool sum probabilities were used with all the ${ }^{14} \mathrm{C}$ measurements to compute cumulative probability distribution per site with two sigma ranges. After calibration, the radiocarbon dates were used to establish age-depth models by exponential smoothing, one per dune profile (cf. in Carcaillet and others 2006). The age-depth models were then used to simulate the ages of undated burned paleosoils. One measurement in each radiocarbon series appeared to be too old compared with the other data: $3316 \pm 85 \mathrm{BP}$ (UQ-2117) at $175 \mathrm{~cm}$ at Villemontel and $1870 \pm 80 \mathrm{BP}$ (UL-1268) at $49 \mathrm{~cm}$ at Lunette. These probably old measurements were thus not used for the establishment of the agedepth models (cf. Carcaillet and others 2006). The age-depth distributions clearly indicated an in- crease in the accumulation rate of sediment in the upper layers of both dune profiles, which was associated with an increase in the number of charred layers. The intervals between the charred layers were regular in terms of thickness rather than in terms of duration.

\section{Charcoal Identification}

About half a litter of charred layer was sampled. Charcoal was extracted from sediments by flotation, and charcoal volumes per layer were measured by displacement of water in a beaker. The measured volume was expressed according to the volume of sampled sediment also measured by water displacement $\left(\mathrm{vol}_{\mathrm{CHAR}} / \mathrm{vol}_{\text {SEDIMENT }}=\%\right)$. The charred particles were very fragmented and looked like a black powder. Where possible, 30 fragments per layer were randomly selected for identification by picking them from the sieve (mesh size $>350 \mu \mathrm{m})$. The identifications were based on wood anatomical structures using an incident light microscope $(\times 200, \times 500, \times 1000)$ and were compared with descriptions of wood in atlases (for example, Jacquiot 1955; Schweingruber 1990) or with wood charcoal in personal reference collections (CC, VR). Larix and Picea could not be distinguished because of their close anatomy (Marguerie and others 2000), resulting in the lumped charcoal taxon Larix/Picea. Three pine species can theoretically be observed in the area: $P$. banksiana, Pinus strobus and Pinus resinosa Aiton. They all present different anatomical structures belonging to three anatomical groups of pine, which secures their identifications at the species level (Jacquiot 1955). Particular attention was devoted to the size and pattern of medulla cells and to the abundance of vessels (transversal section) of Ericaceae wood charcoal for identification to species level wherever possible (Talon and Carcaillet 2004) and to wood porosity for identification of 
Table 2. Radiocarbon dating of charcoal layers from the Villemontel and Lunette Dunes in Abitibi, West Quebec, Canada

\begin{tabular}{|c|c|c|c|c|}
\hline Depth $(\mathrm{cm})$ & Lab. Code & ${ }^{14} \mathrm{C}$ years BP & Range of calibrated years BP (probability) & Dated material \\
\hline \multicolumn{5}{|l|}{ Lunette } \\
\hline 49 & UL- 1268 & $1870 \pm 80$ & 1613-1989 BP (1.00) & Plant macroremains \\
\hline \multirow[t]{3}{*}{89} & UL-1629 & $1760 \pm 100$ & 1415-1464 BP (0.04) & Wood charcoal \\
\hline & & & 1477-1506 BP (0.01) & \\
\hline & & & 1513-1896 BP (0.95) & \\
\hline \multirow[t]{2}{*}{173} & UL-1630 & $2520 \pm 70$ & 2379-2415 BP (0.05) & Wood charcoal \\
\hline & & & $2420-2751$ BP (0.95) & \\
\hline \multirow[t]{2}{*}{193} & UL-1631 & $3130 \pm 80$ & $3144-3512$ ВР (0.98) & Wood charcoal \\
\hline & & & 3527-3558 BP (0.02) & \\
\hline \multirow[t]{4}{*}{209} & UQ-2114 & $4314 \pm 90$ & 4613-4766 BP (0.15) & Wood charcoal \\
\hline & & & 4783-5079 ВР (0.74) & \\
\hline & & & $5104-5136$ BP (0.02) & \\
\hline & & & $5163-5281$ BP $(0.09)$ & \\
\hline \multicolumn{5}{|l|}{ Villemontel } \\
\hline 17 & UQ-2121 & $785 \pm 52$ & 655-796 BP (1.00) & Wood charcoal \\
\hline \multirow[t]{2}{*}{39} & UQ-2122 & $1144 \pm 68$ & 930-1186 BP (0.95) & Wood charcoal \\
\hline & & & $1205-1240$ ВР $(0.05)$ & \\
\hline 127 & UQ-2125 & $1933 \pm 59$ & 1722-1998 BP (1.00) & Wood charcoal \\
\hline \multirow[t]{2}{*}{150} & UQ-2126 & $2125 \pm 45$ & $1989-2184$ BP $(0.84)$ & Wood charcoal \\
\hline & & & 2233-2305 BP (0.16) & \\
\hline \multirow[t]{3}{*}{175} & UQ-2127 & $3316 \pm 85$ & $3368-3726$ ВР (0.97) & Wood charcoal \\
\hline & & & 3750-3762 ВР (0.01) & \\
\hline & & & $3793-3821$ ВР $(0.02)$ & \\
\hline \multirow[t]{3}{*}{187} & UL-1632 & $3270 \pm 100$ & $3246-3309$ ВР (0.04) & Wood charcoal \\
\hline & & & $3318-3724$ ВР $(0.95)$ & \\
\hline & & & $3795-3818$ BP $(0.01)$ & \\
\hline \multirow[t]{3}{*}{203} & UQ-2116 & $3319 \pm 88$ & 3368-3726 BP (0.97) & Wood charcoal \\
\hline & & & 3750-3762 ВР (0.01) & \\
\hline & & & 3793-3821 BP (0.02) & \\
\hline 222 & UQ-2113 & $5525 \pm 72$ & $6168-6454$ BP (1.00) & Wood charcoal \\
\hline
\end{tabular}

UQ corresponds to measurements made at the GEOTOP laboratory (Université du Québec à Montréal, Québec, Canada) and UL to the Centre d'Études Nordiques laboratory (Université Laval, Québec, Canada).

Betula tree versus Betula shrub (Hellberg and Carcaillet 2003). Identifications of plant in the collection respect the flora of Québec (Marie-Victorin and others 1995).

The abundance of charcoal taxa per assemblage was expressed as a frequency (\%), that is, the number of fragments of a given taxon in relation to the total number of identified fragments within a collection of fragments. The occurrence rate was the ratio of the number of assemblages containing a given taxon to the total number of assemblages, whatever the relative abundance of the taxon in each assemblage. The occurrence rate allowed the ubiquity in the environment of the burned taxon to be characterized. For example, a low-abundant species that is always present in the environment (dispersed distribution) has a high rate of occurrence, while a locally abundant species (high local frequency) that is infrequent at the landscape level (having a clustered distribution) has a low occurrence rate. The taxon abundance and occurrence rates are two complementary proxies of fuel mass structure at the landscape level (Carcaillet 2017). Ideally, the burned biomass could be assessed, but consumption biomass and the charcoal production rate should first be calibrated (Fréjaville and others 2013); unfortunately, such data do not exist for these species.

\section{Plant Macroremain and Fungus Identification}

One $600 \mathrm{~cm}^{3}$ sample was retrieved from each layer of charred organic material in the paleosoils for plant macrofossil analysis. Samples were soaked during $45 \mathrm{~min}$ at $90^{\circ} \mathrm{C}$ in a $10 \% \mathrm{KOH}$ solution. The bulk solution was sieved at $150 \mu \mathrm{m}$. Identifications 
were made under a dissecting microscope. The results are expressed as number of pieces. For identification, the remains were compared with plant fragments in reference collections at the Department of Geography of the Université de Montréal, Québec, Canada. This collection of plant fragment was established by Mr. Alayn Larouche, based on identification respecting the flora of Québec (Marie-Victorin and others 1995). A particular attention was given to Cenococcum geophilum, an ectomycorrhizal fungus often counted in paleoecological studies based on macroremains (for example, Scott and others 2010; Lacroix and others 2011). All their sclerotes were counted. This fungus C. geophilum characterizes stress communities, notably as a result of chronic drought (Pigott 1982; Coleman and others 1989; Hasselquist and others 2005). Macroremains must be interpreted in the presence, not in the absence (Supp. Info. S2).

\section{RESUlts}

\section{Stratigraphy and Sedimentology}

In total, 17 charred layers were observed at Villemontel and nine at Lunette. At Villemontel, all sands above the deepest layer (no. 17; $221 \mathrm{~cm}$ below the surface) were from aeolian transportation, with a modal size distribution of $177-250 \mu \mathrm{m}$, that is, fine sands. Below layer no. 17, there were coarser sands, heterogeneous in size and poorly sorted, including gravel-type particles larger than $20 \mathrm{~mm}$ and a rolled pebble layer $(5-50 \mathrm{~mm}$ ), which could be the summit of a paleobeach. At Lunette, all sands were of aeolian origin, with a modal distribution of fine sands of $177-250 \mu \mathrm{m}$. The aeolian dune was excavated more than $1 \mathrm{~m}$ below the deepest layer (no. 9; $208 \mathrm{~cm}$ ) without any traces of pedogenesis being found.

\section{Wood Charcoal Identifications}

In general, the charcoal fragments were very small, often around $1 \mathrm{~mm}$ in size. In total, 232 and 431 fragments were identified at Lunette and Villemontel, respectively (Figure 4A). Large charcoal fragments were more abundant in the deepest layers explaining why more fragments were identified in these layers. Their measured volumes were generally higher in the lower-half layers (Figure 5), excepted in the topmost layer in Lunette $(3 \mathrm{~cm}$ below the dune surface) and in the second topmost layer in Villemontel (17 cm below the surface). At Villemontel, if this $17-\mathrm{cm}$-depth layer is not considered, the volume is significantly lower in the top-half profile compared to the lower-half profile
(Wilcoxon test, $p=0.0016$ ). At Lunette, the difference is not significant even when the $3 \mathrm{~cm}$ layer was excluded.

In the upper layers, fragments were too small for identification. Of the 663 fragments, $8 \%$ were unidentified at Lunette and $4 \%$ at Villemontel, because of bad preservation of anatomical structures or because the fragments were glassy, an outcome of a burning process. At both sites, most charcoal fragments per assemblage corresponded with $P$. banksiana, which was present in all assemblages (Figure 4A, Tables S1 and S2). The deepest charcoal layer at Villemontel (no. 17) was the only layer where $P$. banksiana was not the most frequent taxon: Larix/Picea was the most frequent instead. The abundance of $P$. banksiana charcoal decreased with the decrease in depth. The other tree taxa recorded were cf. Larix (Villemontel no. 4 and 6), cf. Picea (Villemontel no. 17), Larix/Picea (Lunette no. 4, 8 and 9; Villemontel no. 4, 11, 13, and 17) and Abies (Lunette no. 8). Few dwarf shrubs were identified: cf. Empetrum and Ledum/Empetrum. Apart from samples with $100 \%$ P. banksiana, the occurrence rates of all other taxa were low (Figure $4 \mathrm{~A})$.

\section{Macroremain Identifications}

Pinus banksiana was the species with the highest occurrence rate $(85 \%)$ : Only four layers of the 26 did not contain any P. banksiana needles, male or female cone fragments or seeds (Figure 4B). When present, $P$. banksiana showed the highest frequency of remains per assemblage, between 60 and $95 \%$. The other main species (Table S1-S2), based on occurrence rate, were P. mariana (Villemontel 65\%, Lunette $78 \%$ ) and Arctostaphylos uva-ursi (Villemontel 65\%, Lunette 67\%). Secondary species were Aralia hispida (Villemontel 53\%, Lunette $33 \%$ ), Hudsonia tomentosa (Villemontel 29\%, Lunette $78 \%$ ) and Carex sp. (two-sided seed; Villemontel $71 \%$, Lunette $11 \%$ ). All other species showed stochastic occurrences: Abies balsamea, Larix laricina, Diervilla lonicera, Vaccinium angustifolium, Vaccinium vitis-idaea, Prunus pensylvanicum, Viola sp., Comptonia peregrina, Carex spp. (two types), cf. Panicum, Scirpus sp., Equisetum sp. and Lycopodium tristachyum (Table S1-S2).

\section{Ecosystem Trajectories, Plant Richness and Fires}

The ecosystem trajectory could be illustrated by the different vegetation proxies, charcoal, plant macroremains and the sclerote abundance of $C$. 


\section{A Wood charcoal}

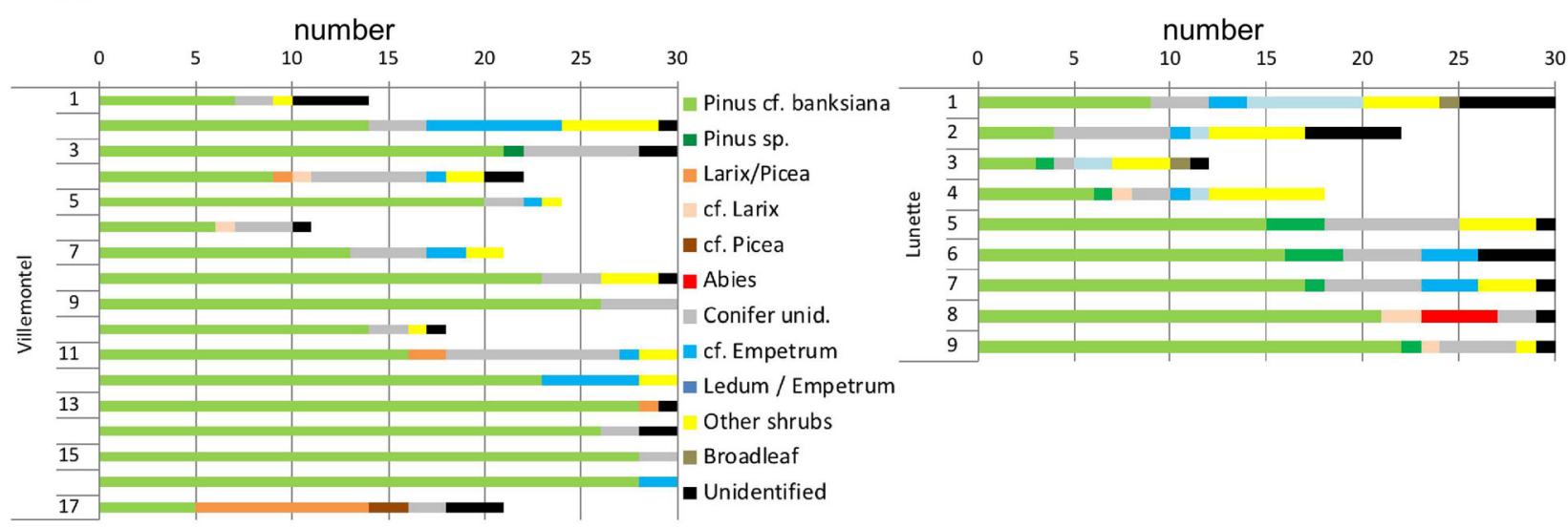

\section{B Plant macroremains}

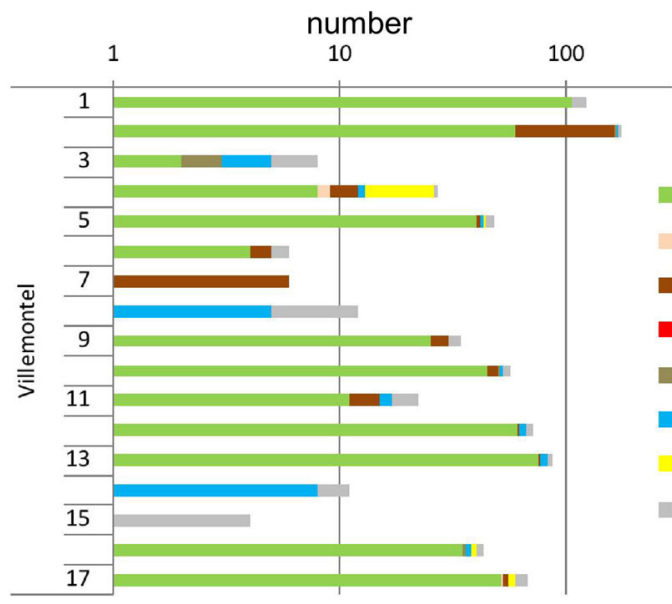

Pinus banksiana

Larix laricina

- Picea marianna

- Abies balsamea

Broadleaf trees

Ericaceae

Other shrubs

Herbs \& Ferns

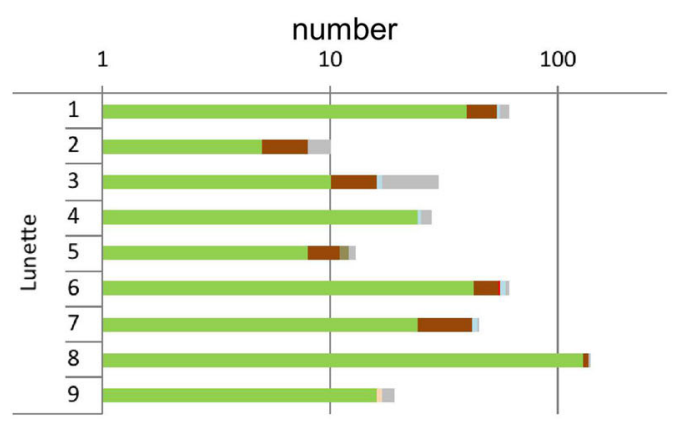

Figure 4. Wood charcoal (number) (A) and plant macroremains (B) (number per cm, log scale) plotted against depth, from the top layer (no. 1) to the deepest (no. 17 at Villemontel [left] and no. 9 at Lunette [right]). Layers are stratified; each layer corresponds to a paleosoil containing charcoal fragments from one or several fires. Details in Table S1 and S2.

geophilum (a fungus), and the richness pattern and fire history (Figure 6). The first layer of charcoal dated to ca $6350 \mathrm{cal} \mathrm{BP}$ at Villemontel and ca $5000 \mathrm{cal} \mathrm{BP}$ at Lunette (Figure 6A). The number of charred layers since $2500 \mathrm{cal} \mathrm{BP}$ at Villemontel $(n=9)$ and Lunette $(n=5)$ was of same order to the number recorded before ( $\mathrm{n}=7$ and 4 , respectively). However, the time intervals were shorter since 2500 cal. BP, suggesting an increase in aeolian activity associated with fires. Each charred layer may be a temporal mix of charcoal fragments from one or several fires and, eventually, a spatial mix if material was blown to the dune. This fact can explain anomalies of chronologies based on old ${ }^{14} \mathrm{C}$ measurement in recent layers.

Both charcoal and macroremain assemblages clearly indicated that $P$. banksiana was the dominant species for at least 6350 years at Villemontel and 5000 years at Lunette. Interestingly, where the plant macroremains failed to reveal $P$. banksiana in four layers at Villemontel (Figure 6C), the charcoal showed that the $P$. banksiana was present with a high percentage of charred fragments (Figure 6B). At both sites, the percentage of $P$. banksiana decreased slightly during the last 4000 years, as illustrated by third-order polynomials: Villemontel $r=0.57$; Lunette $r=0.67$ (Figure 6B, C; values at $0 \%$ were not considered in the calculations because they correspond to absence). At Villemontel, no taxa compensated for this slight decrease in $P$. banksiana, while at Lunette, the assemblages indicated an increase in Ericaceae charcoal and in $P$. mariana macroremains. However, the results of assemblages differ each other, suggesting a stochastic abundance of Ericaceae and Picea. Similarly, at Villemontel, the first charcoal assemblage indicated an important frequency of Larix/Picea, a pattern not supported by the macroremain assemblage (Figure 6B, C). Generally speaking, the apparent difference between two proxies in one 


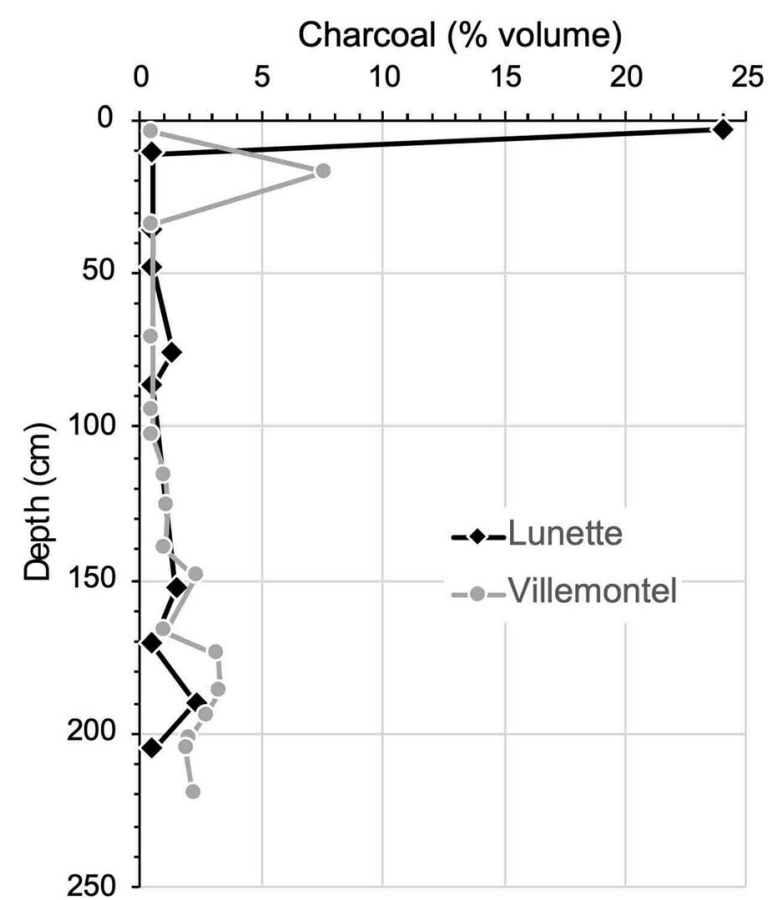

Figure 5. Charcoal concentration profile according to depth below the modern dune soil.

given layer (for example, Villemontel layer no. 8: mainly charcoal of Ericaceae $v s$ macroremains of $P$. banksiana; Figure 6B) should not be understood as a true difference, but simply as a complementary effect of the two proxies, and therefore useful for better describing the diversity of the communities. In Villemontel no. 17, considering that there is no bias due to, for instance, the hazard of identified taxa (here charcoal) associated with low number of observations, the system may have been originally dominated by Larix or Picea and not by Pinus. Further, we also have to consider that the oldest assemblage contains plant remains that may have accumulated over a longer period of time than the later assemblages until first fire on the dune contributes to bury burned soils and associated remains. Finally, the spatial hazard of large woody debris on the ground must be considered as a source of representation bias of vegetation composition or biomass (Ohlson and Tryterud 2000; Bégin and Marguerie 2002; Ohlson and others 2013).

The richness curves were based only on the occurrence of vascular taxa. Both curves (thirdorder polynomials; $r=0.53$ at Villemontel, $r=0.76$ at Lunette) were steady without any significant temporal trend (Figure 6D). They depicted a mean richness \pm SE ( $\alpha$-diversity) of $5.9 \pm 0.7$ taxa at Villemontel and $5.7 \pm 0.5$ taxa at Lunette. These mean values were not distinguishable (Wilcoxon test, $p=0.82$ ).

The ectomycorrhizal fungus $C$. geophilum was present in all layers at Lunette and 13 of the 17 layers at Villemontel (no data in layers no. 7, 8, 14 and 15). The distributions suggested important differences in abundances through time, may be stochastic (Figure 6E). However, no overall trends were evidenced at either site.

\section{Discussion}

This multi-proxy study has revealed similar longterm histories at two sites, even though they were situated $7 \mathrm{~km}$ apart. The vegetation was dominated by Pinus banksiana, although its abundance decreased slightly over 4000 years. Picea mariana was always present but never abundant. Together, the plant macroremains and charcoal compositions per site revealed similar past communities to those that currently dominate the sandy areas, that is, a $P$. banksiana forest with scattered $P$. mariana. The fungus, C. geophilum, was almost always recorded. It characterizes water stress communities as seen currently in the study sites. All other species of trees, shrubs or herbs fluctuated stochastically without a change in plant species richness for at least 6400 years. Objectively, the charcoal layers report a history of fire, but the numbers of paleosoils (layers) do not represent fire abundance at each site. Indeed, the Lunette profile recorded at least nine layers within 5000 years, which would represent a mean apparent fire frequency of 0.0018 fire $\mathrm{ky}^{-1}$, that is, a mean fire interval (MFI) of 560 years. At Villemontel, the 17 charred layers over 6400 years represented a fire frequency of 0.0027 fire $\mathrm{ky}^{-1}$, that is, a MFI of 370 years. The charred layers are definitely fewer in number than the expected number of fires in such a type of ecosystem in the area, which today burn with fire return intervals of about 110 years in average (based on mean stand age, Bergeron and others 2004) and less than 100 years further north (Le Goff and Sirois 2004; Héon and others 2014). Further southwest, in the northwestern Wisconsin plains under continental climate, it was found MFI of 110-140 years using lacustrine charcoal over the past 2500 years around lakes with $P$. banksiana forest on sandy soils (Lynch and others 2014).

Here, both sites presented the same increase in charcoal layers per time unit during the last 2500 years. This pattern suggests that the number of fires has increased during the late Holocene. Interestingly, this observation matches a higher fire occurrence reported in similar dunes/sandy areas 

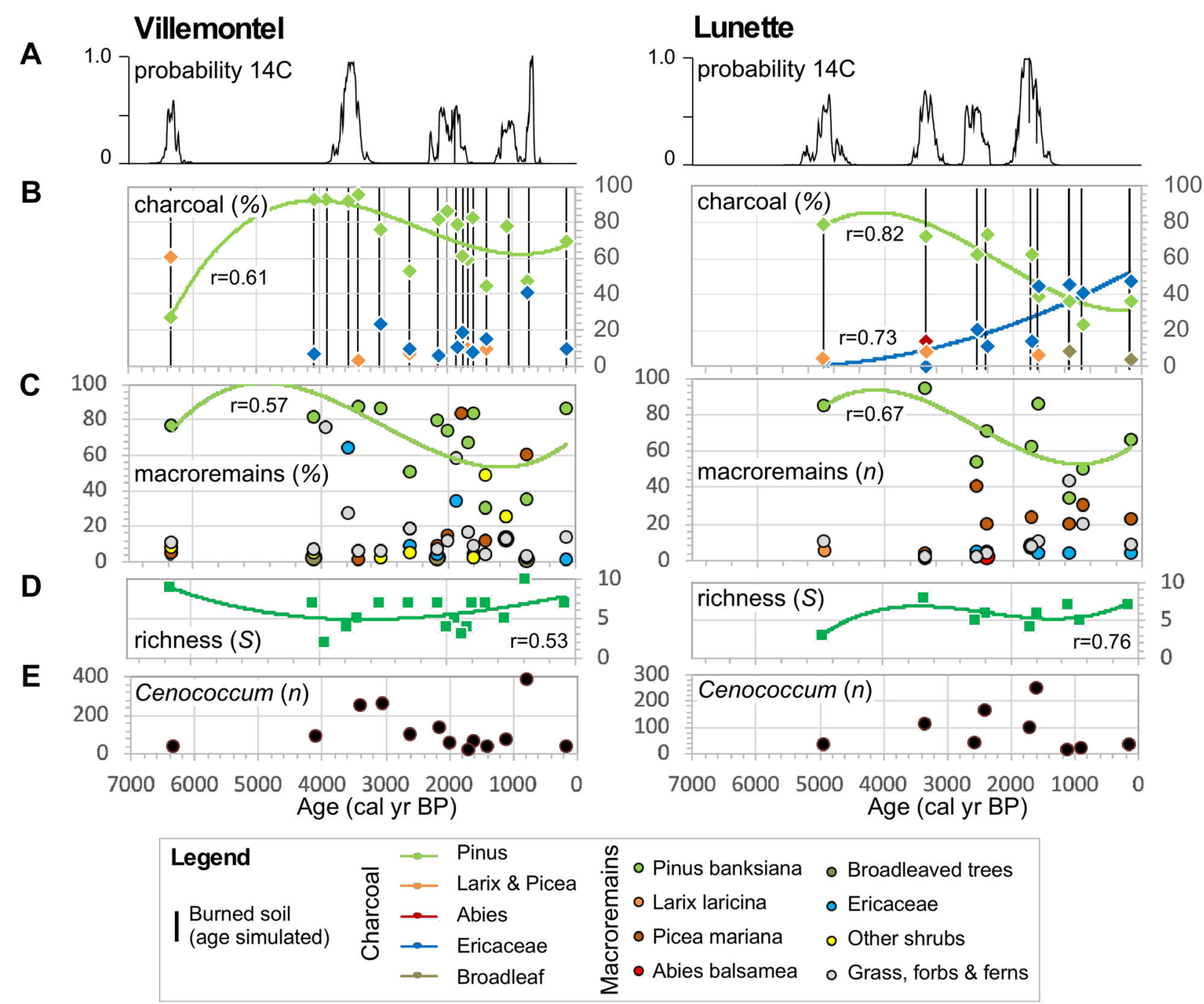

Figure 6. Ecosystem and biodiversity trajectories inferred from assemblages of charcoal and macroremains from paleosoils in western Quebec, Canada. (A) Probability sums of ${ }^{14} \mathrm{C}$ dating. (B) Charcoal frequency (\%) and temporal distribution modeled using polynomials (third order for Pinus banksiana; second order for Ericaceae); unidentified charcoal was used to calculate percentages; the vertical bars correspond to ages of burned paleosoils simulated based on age-depth models (cf. Carcaillet and others 2006); Pinus corresponds to identified charcoal of P. banksiana (major) and Pinus sp. (minor); Larix and Picea include all fragments identified as cf. Larix, cf. Picea and undifferentiated Larix/Picea. (C) Plant macroremain frequency $(\%)$ and temporal distribution of P. banksiana based on third-order polynomials. (D) Vascular plant richness based on pooled assemblages of charcoal and macroremains; time distribution based on third-order polynomials. (E) Sclerote numbers of Cenococcum geophilum, an ectomycorrhizal fungus.

during the last 2000 years in a forest-tundra region situated about $500 \mathrm{~km}$ further north (Filion and others 1991; Desponts and Payette 1993; Arseneault and Sirois 2004). A fire reconstruction based on sedimentary charcoal in Lake Pas-de-Fond, situated on an esker about $30 \mathrm{~km}$ west of the present study sites, also indicated an increase in fire frequency over the last 2200 years (Carcaillet and others 2001), and more generally in the boreal shield since 3000-2500 years although the fire cycle has tremendously increased since the middle nineteenth century (Le Goff and others 2007; Hennebelle and others 2018). Taken together, this evidence suggests local fire activity coherent with a regional pattern in $P$. banksiana dry areas that has become more active after $2500 \mathrm{cal} \mathrm{BP}$.

\section{A Long-Term Steady State}

The forest appears to have been rather stable for 5000 years, as indicated by plant richness and composition, and sclerote abundances of the ectomycorrhizal fungus C. geophilum (Figure 6). 
According to the relationship between ecosystem and community composition (de Mazancourt and others 2013), this biotic stability would illustrate the stability of the ecosystem despite likely change in fire occurrences. Richness stability has already been reported regionally, based on pollen data from lake sediments in this area (Carcaillet and others 2010) and more widely in the eastern Canadian shield (Blarquez and others 2014). A permanent but stochastic abundance of sclerotes has also been recorded in similar macroremain assemblages from a dune site $500 \mathrm{~km}$ to the north (Figure S2 redrawn from Lacroix and others 2011 , to match the present Figure 6). However, the stochastic distribution of sclerote abundances hinders any correlation with other proxies, including fire history or P. banksiana charcoal and macroremains.

The only significant change was a multi-millennial and monotonic decrease in $P$. banksiana, indicated by the percentages represented in charcoal and macroremains at both sites (Figure 6B, C). The change represents a decrease by $40 \%$ during the last 4000 years, that is, $1 \%$ of decrease per century, which is a slight rate of change. This pattern supports a regional trend driven by local mechanisms. However, this trend does not match the timing of change in the frequency of charred layers around $2500 \mathrm{cal} \mathrm{BP}$, indicating that the slight and monotonic decrease in $P$. banksiana abundance was not directly linked to a change in fire frequency or to a single fire exceptional in severity. An indirect linkage cannot be ruled out and could be the result of accumulated fires on populations of $P$. banksiana causing a demographic effect related to the length of fire intervals, which were probably locally longer around $5000 \mathrm{cal}$ BP matching regional fire frequency reconstructions (Carcaillet and others 2010; Hennebelle and others 2018) or regional biomass burning activity in the eastern Canadian shield boreal forest (Bremond and others 2010). P. banksiana is a short-living species (Desponts and Payette 1992), and potentially more competitive species (P. mariana, P. glauca, Abies balsamea) have better longevity and better regeneration rates with time since last fire (Bergeron and Dansereau 1993; Le Goff and Sirois 2004; Smirnova and others 2008). However, no taxa appeared to be clearly favored by the decrease in P. banksiana, and no clear pattern of pine substitution was obvious (Figure 6B, C). Although not significant, percentages of ericaceous charcoal increased more at Lunette than at Villemontel; however, the macroremains showed no such pattern. This percentage increase could be the mathematical result of a decrease in pine percentage without any underlying biological mechanism, that is, a bias of data representation typical of percentage data. Indeed, the macroremains show higher numbers of $P$. mariana fragments, especially at Lunette (Figure $4 \mathrm{~B}$ ), but no distribution trend could be modeled (Figure 6C), and this was not supported by the charcoal data (Fig. 4A). A biological explanation for the multi-millennial decrease in P. banksiana could be a reduction in pine biomass or density linked to repeated crown fires without an effect on other canopy species (Arseneault 2001; Pacé and others 2019b). This mechanism probably involves a ground mat of lichens that reduces the regeneration and growth of pine seedlings due to different soil processes, for example, nutrient inhibition, depleted mycorrhizal activity or antimicrobial reactions (Pacé and others 2019a, b). The high charcoal occurrence $(65-67 \%)$ of the dwarf ericaceous $A$. uva-ursi strengthens this hypothesis of soil processes limiting pine recruitment. Indeed, leaf leachate of A. uva-ursi generates high concentrations of phenolic compounds that reduce nitrification rates and thus inhibit pine regeneration (MacKenzie and DeLuca 2006). The observed progressive decrease in $P$. banksiana $\left(1 \% 100 \mathrm{y}^{-1}\right)$ could just result from a slight and monotonic decrease in tree productivity and an increase in ground lichen cover and associated soil functionality (Pacé and others 2019a). Unfortunately, lichen cover cannot be recorded by current paleoecological methods. Interestingly, pollenbased studies from lakes surrounded by jack pine generally show a slight increase in $P$. banksiana percentage since less than 3000 years in the area (Liu 1990; Garralla and Gajewski 1992; Carcaillet and others 2001), in the north (Richard 1979; Gajewski and others 1996) or in the southwest (for example, Brubaker 1975; Genries and others 2012; Lynch and others 2014). However, when these data are expressed in influx, the pattern can be different, revealing a decreasing trend during the last millennia (Carcaillet and others 2010) or no change (Liu 1990) suggesting that some long-term processes occurred on jack pine woodlands depending on sites. Generally, these lacustrinebased studies did not include plant remains, and when this proxy was used (Liu 1990), it is interesting to note a general absence of remains of $P$. banksiana.

Contrary to boreal mountains of southern Quebec that experienced a switch under the effect of disturbances during the Holocene from closed and tree-diversified forest to an alternative steady ecosystem characterized by open taiga woodland dominated by Picea and ground lichens (Jasinski 
and Payette 2005), our study context indicates continuous record of Pinus without plant diversity erosion nor obvious transformation of the system. In summary, the ecosystem state appears to be steady in terms of plant richness and composition whatever the fire conditions, although the modeled distribution of $P$. banksiana percentage reveals a gentle and monotonic decrease over the last 4000 years. Fire regimes cannot be accurately reconstructed based on the type of data used here; however, the system autocorrelated well in time despite frequent disturbances and water stress, supporting the idea of high resistance (inertia of the system after a disturbance or a stressor effect; Connell and Sousa 1983) or high resilience (recovery rate that is a function of resistance and the time required to return to the initial state after disturbance or a stressor; Holling 1973). Resistance and resilience are two different concepts in disturbance ecology, but they are linked (Walker and others 2004; Nimmo and others 2015); resistance is an intrinsic component of resilience (Figure S1).

\section{Resilient or Resistant?}

The ecosystem was steady over time according to the following facts: (1) P. banksiana has dominated the whole series despite a slight decrease and thus figures its contribution to total primary productivity of the ecosystem ('mass-ratio hypothesis'; Grime 1998), (2) the species richness was stable despite the stochastic record, (3) the fungus C. geophilum occurred permanently despite a high variance in sclerote numbers, and (4) a likely increase in fire occurrences after $2500 \mathrm{cal}$ BP not correlated with changes in plant assemblages. It has thus maintained an elevated temporal autocorrelation (similarity between two consecutive observations; permanent dominance of $P$. banksiana) whatever disturbances or other climate changes that, in the first instance, could support hypotheses of high resistance (large inertia) but also of high resilience thanks to strong recovery rate. This means that, whatever the resistance of the system, strong or weak, the recovery rate was high and brief (Figure $1 \mathrm{~A}, \mathrm{~B}$ ) and the variance of the system was low because never alternative species dominated instead of P. banksiana, thus rejecting the scenario of a large basin of attraction (Figure $1 \mathrm{C}$ ). A recovery time longer than the fire intervals $\left(R_{\lambda}=\right.$ $\mathrm{d} t_{\varphi}: \mathrm{d} t_{\lambda}<1$ ) altering the ecosystem state is probably not realistic (Figure 1D), because no intermediate species were detected in the record (Ericaceae, Betula, Salix, etc.), and the pine record was continuous. Further, if very long delayed recovery time occurred (MFI $>200$ y), the system would have switched to a dominance of $P$. mariana, whatever the fire severity (Le Goff and Sirois 2004; Smirnova and others 2008), a species little recorded. If a very short recovery time occurred due to too frequent fire (MFI $<50 \mathrm{y})$, the system would have switched to a non-forest community of shrubs, lichens and herbs (Hart and others 2018); shrubs and herbs are taxa well recorded in plant macroremains or charcoal but stochastic and never abundant (Figure 4). Even if fire frequencies had varied during the past 6000 years, they were probably within the range of intervals observed during the last two centuries (Le Goff and others 2007; Héon and others 2014). This situation is guaranteed, at least, by the short recovery time of pine canopy, and has led to a strong resilience of this ecosystem whatever its resistance.

The possibility that the ecosystem resistance was weak (Figure 1B) or strong (Figure 1A) has to be considered as a theoretical hypothesis. The weak resistance associated with a fire-prone community assumes that the resilience potential of the ecosystem thanks to a rapid recovery time associated with high autocorrelation offsets the temporary loss of functionality as a result of disturbance. In contrast, the strong resistance assumes that, whatever the environmental changes (chronic, as with climate change or soil maturation, or transitory, as with disturbance), the functionality of the system does not change, which includes the plant community that is manifested by the complex functioning of the ecosystem (analogy with a response trait for an organism). Today, dry sandy areas in Canadian boreal forests mainly host $P$. banksiana and $P$. mariana in the canopy and ericaceous or ground lichens in the understory. Pinus abundance is controlled by fires (Johnson 1992) but is generally excluded by intervals of stand-replacing fire longer than 200 years, while P. mariana is excluded by intervals shorter than 60 years (Desponts and Payette 1992; Le Goff and Sirois 2004; Splawinski and others 2019). Temporary modification of the canopy from $P$. banksianadominant to Picea dominant during the last 6000 years would thus show a loss of autocorrelation over a period of 500 to 1000 years. Such loss would result from the elongation of fire-free intervals altering the understory and biogeochemical properties, notably an increase in residence time of organic matter, which potentially favors the regeneration of $P$. mariana by layering (Laberge and others 2001; Figure 2) and alters ectomycorrhizal functionalities (Pacé and others 2019a). The only trend associated with the gentle decrease in pine is 
the slight augmentation of Ericaceae recorded in the charcoal assemblages of Lunette (Figure 6B), which might be linked to more severe fires stimulating ericaceous species instead of Cladina-type lichens more adapted to less severe fires (Arseneault 2001; Pinno and Errington 2016). However, the assemblages from Villemontel do not show such a pattern, suggesting that fire severity finally did not change significantly over time. Furthermore, Picea was never dominant at either Lunette or Villemontel, suggesting that the fire intervals remained short (high fire frequency) and the fires were severe enough to hinder Picea regeneration by seed or by layering (Walker and others 2018). Based on our paleobotanical data, the scenario of elongation of fire-free intervals is thus not realistic and was certainly not met during the last 6000 years. Finally, the decrease in pine abundance revealed by both macroremains and charcoal at both sites may illustrate a sustained inhibition of pine regeneration that could be the result of soil processes linked to the ground mat of lichens (Pacé and others 2019a) or ericaceous species (Nilsson and Wardle 2005). The high regeneration of pine in a highfrequency fire regime explains the steady state (autocorrelation), and the partial inhibition of pine regeneration or growth (Pacé and others 2019a) explains the slight trend observed over millennia, that is, a decrease in pine percentage. The system would thus tend to be resistant.

Interestingly, in regional sites situated $500 \mathrm{~km}$ further north, P. banksiana and P. mariana were either codominant for 4800 years (Arseneault and Sirois 2004), where Picea abundance decreased in favor of $P$. banksiana less than 3000 years ago, suggesting a fire-linked ecosystem functioning (Desponts and Payette 1993; Lacroix and others 2011). The pattern reported in Lacroix and others (2011; Figure S2) seems rather important, triggering the rarefaction of Picea and eventually the creation of an alternative state dominated by pine. Contrary to these observations at sites close to the forest-tundra transition, ca. $500 \mathrm{~km}$ north of the current study sites, our present observations from the core of the boreal forest indicate that a steady state dominated by pine was initially established 6400 years ago. Because over millennia the canopy species ( $P$. banksiana) is also the plant that recruits abundantly shortly after a fire, the ecosystem appears to be at least as resistant as it is resilient to all accumulated environmental changes.

Finally, the continuous but slight decrease in abundance of the dominant tree (Figure 6) would figure the slight decrease in ecosystem functionality (sensu 'mass-ratio hypothesis'; Grime 1998) despite indicators suggesting a metastable system over time. However, this slight decrease within a general steady state is associated with a disturbance regime (here underestimated by analogy with modern context of the eastern Canadian boreal forest, for example, Le Goff and others 2007; Héon and others 2014), which questions the hypothesis that a forest ecosystem needs disturbance to secure its high productivity by stimulating microbial activities and biogeochemical processes (Wardle and others 2004; Petzler and others 2010). The fire frequency during the last 4000 years was maybe not high enough to stimulate processes associated with bacterial flora instead of fungi flora, which should promote an increase in forest productivity (Wardle and others 2004). Or, fires were too frequent preventing the growth of other tree species (Picea, Betula, Alnus), which would have effects increase the ecosystem productivity notably by complexing the trophic network, reducing the strength of demographic stochasticity and enhancing compensatory processes (de Mazancourt and others 2013). However, fires were maybe too severe to allow for a good regeneration and soil functionality. Whatever the theory and generalization, here the chronology shows a general steady system frequently disturbed by fires with a slight decrease in the only dominant species suggesting a slight diminution of the productivity over time. This paleoecological analysis matches a modern large-scale spatial analysis indicating a high resilience of $P$. banksiana forest with current regime of fire frequency (Hart and others 2018). Ecosystem dominated by Pinus banksiana on dry soils is thus a multi-millennial steady state and resilient ecosystem.

\section{ConClusion}

Dry sandy areas of the east Canadian boreal forest have been stable and covered by P. banksiana for at least 6000 years despite harsh conditions resulting from frequent burnings and a substratum subjected to water stress. This is a general context theoretically reducing the role of competition as driver, and thus selecting species adapted to stress and disturbances (Grime 1977). Tree-cover and species diversity remained relatively stable, despite the presence of other species adapted to stress or disturbances, for example, P. mariana and Ericaceae. The only transient modification has been a multimillennial, slight decrease in $P$. banksiana abundance without any clear substitution by another species or species group. The system appears to be resistant and mostly resilient, leading to a high 
autocorrelation without rapid change in plant communities and richness, which represents an ecosystem characterized by a steady state. However, because the ecosystem resilience is not total, the ecosystem has changed subtly over millennia, recording a slight reduction in $P$. banksiana abundance with a rate of $1 \%$ per century.

\section{ACKNOWLEDGMENTS}

We warmly thank both reviewers for their impressive and constructive reviews. We thank Alayn C. Larouche for help with the botanical identifications of macroremains. Financial support was provided by the Natural Sciences and Engineering Research Council (Canada). The research was carried out within the framework of the International Associated Laboratory (LIA FranceCanada) CNRS-UM2-EPHE-UQAT-UQAM-UQAC, entitled MONTABOR: Mountain and Boreal Forests, Chronoecology and Sustainable Ecosystemic Management. C.C. and Y.B. acknowledge support from the European Commission through the Marie Curie IRSES program NewForests (PIRSES-GA2013-612645). The English text was edited by SEES-Editing Ltd.

\section{Compliance with Ethical Standards}

Conflict of interest The authors declare no competing interests.

\section{OPEN ACCESS}

This article is distributed under the terms of the Creative Commons Attribution 4.0 International License (http://creativecommons.org/licenses/by/4 $.0 /$ ), which permits unrestricted use, distribution, and reproduction in any medium, provided you give appropriate credit to the original author(s) and the source, provide a link to the Creative Commons license, and indicate if changes were made.

\section{REFERENCES}

Allard M. 1974. Géomorphologie des eskers abitibiens. Cahiers de géographie du Québec 18:271-96.

Arseneault D. 2001. Impact of fire behavior on postfire forest development in a homogeneous boreal landscape. Canadian Journal of Forest Research 31:1367-74.

Arseneault D, Sirois L. 2004. The millennial dynamics of a boreal forest stand from buried trees. Journal of Ecology 92:490-504.

Barber DC, Dyke A, Hillaire-Marcel C, Jennings AE, Andrews JT, Kerwin MW, Gagnon JM, Gagnon JM. 1999. Forcing of the cold event of 8,200 years ago by catastrophic drainage of Laurentide lakes. Nature 400:344-8.
Bégin Y, Marguerie D. 2002. Characterization of tree macroremains production in a recently burned conifer forest in northern Québec, Canada. Plant Ecology 159:143-52.

Bélanger N, Carcaillet C, Padbury GA, Harvey-Schafer AN, Van Rees KJC. 2014. Periglacial fires and trees in a continental setting of central Canada, Upper Pleistocene. Geobiology 12:109-18.

Bergeron Y, Dansereau PR. 1993. Predicting the composition of Canadian southern boreal forest in different fire cycles. Journal of Vegetation Science 4:827-32.

Bergeron Y, Gauthier S, Flannigan M, Kafka V. 2004. Fire regimes at the transition between mixed wood and coniferous boreal forest in Northwestern Quebec. Ecology 85:1916-32.

Birks HH, Birks HJB. 2000. Future uses of pollen analysis must include plant macrofossils. Journal of Biogeography 27:31-5.

Blarquez O, Aleman JC. 2016. Tree biomass reconstruction shows no lag in post-glacial afforestation of eastern Canada. Canadian Journal of Forest Research 46:485-98.

Blarquez O, Carcaillet C, Frejaville T, Bergeron Y. 2014. Disentangling the trajectories of alpha, beta and gamma plant diversity of North American boreal ecoregions since 15,500 years. Frontiers in Ecology and Evolution 2:6. https://doi.org/ 10.3389/fevo.2014.00006.

Bremond L, Carcaillet C, Favier C, Ali AA, Paitre C, Bégin Y, Bergeron Y, Richard PJH. 2010. Effects of vegetation zones and climatic changes on fire-induced atmospheric carbon emissions: a model based on paleodata. International Journal of Wildland Fire 19:1015-25.

Briand CH, Schwilk DW, Gauthier S, Bergeron Y. 2015. Does fire regime influence life history traits of jack pine in the southern boreal forest of Québec, Canada? Plant Ecology 216:157-64.

Brown RT, Mikola P. 1974. The influence of fruticose soil lichens upon the mycorrhizae and seedling growth of forest trees. Acta Forestalia Fennica 141:1-23.

Brubaker LB. 1975. Postglacial forest patterns associated with till and outwash in northcentral upper Michigan. Quaternary Research 5:499-527.

Carcaillet C. 2017. Unlimited fuel wood during the middle Mesolithic (9650-8300 cal. yr BP) in northern Sweden: fuel typology and pine-dominated vegetation inferred from charcoal identification and tree-ring morphology. The Holocene 27:1370-8.

Carcaillet C, Bergeron Y, Richard PJH, Fréchette B, Gauthier S, Prairie YT. 2001. Change of fire frequency in the eastern Canadian boreal forests during the Holocene: does vegetation composition or climate trigger the fire regime? Journal of Ecology 89:930-46.

Carcaillet C, Richard PJH, Asnong H, Capece L, Bergeron Y. 2006. Fire and soil erosion history in east Canadian boreal and temperate forests. Quaternary Science Reviews 25:1489-500.

Carcaillet C, Richard PJH, Bergeron Y, Fréchette B, Ali AA. 2010. Resilience of the boreal forest in response to Holocene firefrequency changes assessed by pollen diversity and population dynamics. International Journal of Wildland Fire 19:1026-39.

Coleman MD, Bledsoe CS, Lopushinsky W. 1989. Pure culture response of ectomycorrhizal fungi to imposed water stress. Canadian Journal of Botany 67:29-39.

Connell JH, Sousa WP. 1983. On the evidence needed to judge ecological stability or persistence. The American Naturalist 121:789-824. 
Couillard PL, Payette S, Lavoie M, Frégeau M. 2018. Macrocharcoal-based chronosequence reveal shifting dominance of conifer boreal forest under changing fire regime. Ecosystems 21:1183-95.

Day NJ, Carrière S, Baltzer JL. 2017. Annual dynamics and resilience in post-fire boreal understory vascular plant communities. Forest Ecology and Management 401:264-72.

de Groot WJ, Bothwell PM, Taylor SW, Wotton BM, Stocks BJ, Alexander ME. 2004. Jack pine regeneration and crown fires. Canadian Journal of Forest Research 34:1634-41.

de Mazancourt C, Isbell F, Larocque A, Berendse F, De Luca E, Grace JB, Haegeman B, Polley HW, Roscher C, Schmid B, Tilman D, van Ruijven J, Weigelt A, Wilsey BJ, Loreau M. 2013. Predicting ecosystem stability from community composition and biodiversity. Ecology Letters 16:617-25.

Desponts M, Payette S. 1992. Recent dynamics of jack pine at its northern distribution limit in northern Quebec. Canadian Journal of Botany 70:1157-67.

Desponts M, Payette S. 1993. The Holocene dynamics of jack pine at its northern range limit in Quebec. Journal of Ecology 81:719-27.

Filion L. 1984. A relationship between dunes, fire and climate recorded in the Holocene deposits of Quebec. Nature 309:5436.

Filion L, Saint-Laurent D, Desponts M, Payette S. 1991. The Late Holocene record of aeolian and fire activity in northern Québec, Canada. The Holocene 1:201-8.

Fonda RW. 2001. Burning characteristics of needles from eight pine species. Forest Science 47:390-6.

Fréjaville T, Carcaillet C, Curt T. 2013. Calibration of charcoal production from trees biomass for soil charcoal analyses in subalpine ecosystems. Quaternary International 289:16-23.

Marie-Victorin F, Rouleau E, Brouillet L. 1995. Flore Laurentienne. 3rd edn. Montréal, Québec, Canada: Presse de l’Université de Montréal.

Gajewski K, Garralla S, Milot-Roy V. 1996. Postglacial vegetation at the northern limit of lichen woodland in northwestern Québec. Géographie physique et Quaternaire 50:341-50.

Garralla S, Gajewski K. 1992. Holocene vegetation history of the boreal forest near Chibougamau, central Quebec. Canadian. Journal of Botany 70:1364-8.

Gauthier S, Bergeron Y, Simon JP. 1996. Effects of fire regime on the serotiny level of jack pine. Journal of Ecology 84:539-48.

Gauthier S, Bernier P, Kuuluvainen T, Shvidenko AZ, Schepaschenko DG. 2015. Boreal forest health and global change. Science 349:819-22.

Genries A, Finsinger W, Asnong H, Bergeron Y, Carcaillet C, Garneau M, Hely C, Ali AA. 2012. Local versus regional processes: can soil characteristics overcome climate and fire regimes by modifying vegetation trajectories? Journal of Quaternary Science 27:745-56.

Greene DF, Macdonald SE, Haeussler S, Domenicano S, Noël J, Jayen K, Charron I, Gauthier S, Hunt S, Gielau ET, Bergeron Y, Swift L. 2007. The reduction of organic-layer depth by wildfire in the North American boreal forest and its effect on tree recruitment by seed. Canadian Journal Forest Research $37: 1012-23$.

Grime JP. 1977. Evidence for the existence of three primary strategies in plants and its relevance to ecological and evolutionary theory. The American Naturalist 111:1169-94.
Grime JP. 1998. Benefits of plant diversity to ecosystems: Immediate, filter and founder effects. Journal of Ecology 86:902-10

Hart SJ, Henkelman J, McLoughlin PD, Nielsen SE, TruchonSavard A, Johnstone JF. 2018. Examining forest resilience to changing fire frequency in a fire prone region of boreal forest. Global Change Biology 25:869-84.

Hasselquist N, Germino MJ, McGonigle T, Smith WK. 2005. Variability of Cenococcum colonization and its ecophysiological significance for young conifers at alpine-treeline. New Phytologist 165:867-73.

Hellberg E, Carcaillet C. 2003. Wood anatomy of West-European Betula: quantitative descriptions and applications for routine identification in paleoecological studies. Ecoscience 10:370-9.

Hennebelle A, Grondin P, Aleman JC, Ali A, Bergeron Y, Bocar D, Blarquez O. 2018. Using paleoecology to improve reference conditions for ecosystem-based management in western spruce-moss subdomain of Québec. Forest Ecology and Management 430:157-65.

Héon J, Arseneault D, Parisien MA. 2014. Resistance of the boreal forest to high burn rates. Proceedings of the National Academy of Sciences of the USA 11:13888-93.

Holling S. 1973. Resilience and stability of ecological systems. Annual Review of Ecological Systems 4:1-23.

Jacquiot C. 1955. Atlas d'anatomie des bois de conifères. Paris, France: Centre technique du bois.

Jasinski JPP, Payette S. 2005. The creation of alternative stable state in the southern boreal forest, Québec, Canada. Ecological Monographs 75:561-83.

Johnson EA. 1992. Fire and vegetation dynamics: studies from the North American boreal forest. Cambridge University Press.

Laberge MJ, Payette S, Pitre N. 2001. Development of stunded black spruce (Picea mariana) clones in the subarctic environment: a dendroarchitectural analysis. Ecoscience 8:489-98.

Lacroix C, Lavoie M, Bhiry N. 2011. New macrofossil evidence for early postglacial migration of jack pine (Pinus banksiana) in the James Bay region of northwestern Quebec. Ecoscience $18: 273-8$

Lavoie L, Sirois L. 1998. Vegetation changes caused by recent fires in the northern boreal forest of eastern Canada. Journal of Vegetation Science 9:483-92.

Le Goff H, Sirois L. 2004. Black spruce and Jack pine dynamics simulated under varying fire cycles in the northern boreal forest of Quebec. Canadian Journal of Forest Research 34:2399-409.

Le Goff H, Flannigan MD, Bergeron Y, Girardin MP. 2007. Historical fire regime shifts related to climate teleconnections in the Waswanipi area, central Quebec, Canada. International Journal of Wildland Fire 16:607-18.

Liu KB. 1990. Holocene paleoecology of the boreal forest and Great Lakes-St Lawrence forest in northern Ontario. Ecological Monographs 60:179-212.

Lynch EA, Calcote R, Hotchkiss SC, Tweiten M. 2014. Presence of lakes and wetlands decreases resilience of jack pine ecosystems to late-Holocene climatic changes. Canadian Journal of Forest Research 44:1331-43.

MacKenzie MD, DeLuca TH. 2006. Charcoal and shrubs modify soil processes in ponderosa pine forests of western Montana. Plant and Soil 287:257-66.

Marguerie D, Bégin Y, Cournoyer L. 2000. Distinction anatomique du bois du Mélèze (Larix laricina), de l'épinette blanche (Picea glauca) et de l'épinette noire (Picea mariana) en vue de 
l'analyse des macrorestes. Géographie physique et Quaternaire 54:317-25.

Matthews JA, Seppälä M. 2014. Holocene environmental change in subarctic aeolian dune fields: The chronology of sand dune re-activation events in relation to forest fires, palaeosol development and climatic variations in Finnish Lapland. The Holocene 24:149-64.

McLauchlan KK, Higuera PE, Gavin DG, Perakis SS, Mack MC, Alexander H, Williams JJ, Williams JJ. 2014. Reconstructing disturbances and their biogeochemical consequences over multiple timescales. BioScience 64:105-16.

Moen J, Rist L, Bishop K, Chaplin FSIII, Ellison D, Kuuluvainen T, Petersson H, Puettmann KJ, Rayner J, Warkentin IG, Bradshaw CJA. 2014. Eye on the taiga: removing global policy impediments to safeguard the boreal forest. Conservation Letters 7:408-18.

Müller F, Bergmann M, Dannowski R, Dippner JW, Gnauck A, Haase P, Jochimsen MC, Kasprzak P, Kröncke I, Kümmerlin M, Küster M, Lischeid G, Meesenburg H, Merz C, Millat G, Müller J, Padisák J, Schimming CG, Schubert H, Schult M, Selmeczy G, Shatwell T, Stoll S, Schwabe M, Soltwedel T, Straile D, Theuerka M. 2016. Assessing resilience in long-term ecological data sets. Ecological Indicators 65:10-43.

Nilsson MC, Wardle DA. 2005. Understory vegetation as a forest ecosystem driver: Evidence from the northern Swedish boreal forest. Frontiers in Ecology and the Environment 3:421-8.

Nimmo DG, Rally RM, Cunningham SC, Haslem A, Bennet AF. 2015. Vive la résistance: reviving resistance for 21 st century conservation. Trends in Ecology and Evolution 30:516-23.

Ohlson M, Kasin I, Wist AN, Bjune AE. 2013. Size and spatial structure of the soil and lacustrine charcoal pool across a boreal forest watershed. Quaternary Research 80:417-24.

Ohlson M, Tryterud E. 2000. Interpretation of the charcoal record in forest soils: forest fires and their production and deposition of macroscopic charcoal. The Holocene 10:519-25.

Oliver TH, Heard MS, Isaac NJB, Roy DB, Procter D, Eigenbrod F, Bullock JM, Bullock JM. 2015. Biodiversity and resilience of ecosystem functions. Trends in Ecology and Evolution 30:673-84.

Pacé M, Fenton NJ, Paré D, Stefani FOP, Massicotte HB, Tackaberry LE, Bergeron Y. 2019a. Lichens contribute to open woodland stability in the boreal forest through detrimental effects on pine growth and root ectomycorrhizal development. Ecosystems 22:189-201.

Pacé M, Gadet B, Beguin J, Bergeron Y, Paré D. 2019b. Drivers of boreal tree growth and stand opening: the case of jack pine on sandy soils. Ecosystems, in-press:000-000. https://doi.org/10. 1007/s10021-019-00425-2.

Payette S, Delwaide A, Couillard PL, Pilon V. 2017. Disjunct jack pine (Pinus banksiana) populations of the boreal forest in eastern Canada: expanding, declining, or stable? Botany 95:697-707.

Petzler D, Wardle DA, Allison VJ, Baisden WT, Bardgett R, Chadwick OA, Condron LM, Parfitt RL, Porder S, Richardson SJ, Turner BL, Vitousek PM, Walker J, Walker LR. 2010. Understanding ecosystem retrogression. Ecological Monographs 80:509-29.

Pigott CD. 1982. Survival of mycorrhiza formed by Cenococcum geophilum Fr. in dry soils. New Phytologist 92:513-17.

Pinno BD, Errington RC. 2016. Burn severity dominates understory plant community response to fire in xeric jack pine forests. Forests 7:83.
Pinno BD, Errington RC, Thompson DK. 2013. Young jack pine and high severity fire combine to create potentially expansive areas of understocked forest. Forest Ecology and Management 310:517-22.

Radeloff VC, Mladenoff DJ, Guries RP, Boyce MS. 2004. Patterns of cone serotiny in Pinus banksiana in relation to fire disturbance. Forest Ecology and Management 189:133-41.

Reimer PJ, Bard E, Bayliss A, Warren Beck J, Blackwell PG, Bronk Ramsey $C$ et al. 2013. IntCall3 and Marinel3 radiocarbon age calibration curves $0-50,000$ years cal. B.P. Radiocarbon 55:1869-87.

Richard PJH. 1979. Contribution à l'histoire postglaciaire de la végétation au nord-est de la Jamésie, Nouveau-Québec. Géographie physique et Quaternaire 33:93-112.

Richard PJH. 1995. Le couvert végétal du Québec-Labrador il y a 6000 ans BP: essai. Géographie physique et Quaternaire 49:117-40.

Robin V, Talon B, Nelle O. 2013. Pedoanthracological contribution to forest naturalness assessment. Quaternary International 289:10-15.

Scheffer M, Carpenter S, Foley JA, Folke C, Walker B. 2001. Catastrophic shift in ecosystems. Nature 413:591-6.

Schmidt MG, Carmean WH. 1988. Jack pine site quality in relation to soil and topography in north central Ontario. Canadian Journal of Forest Research 18:297-305.

Schweingruber FH. 1990. Anatomie europaïscher Hölzer. Bern, Switzerland: Paul Haupt Verlag.

Scott AC, Pinter N, Collinson ME, Hardiman M, Anderson RS, Brain APR, Smith SY, Marone F, Stampanoni M. 2010. Fungus, not comet or catastrophe, accounts for carbonaceous spherules in the Younger Dryas "impact layer". Geophysical Research Letters 37:L14302.

Sedia EG, Ehrenfeld JG. 2006. Differential effects of lichens and mosses on soil enzyme activity and litter decomposition. Biology and Fertility of Soils 43:177-89.

Seppälä M. 1995. Deflation and redeposition of sand dunes in Finnish Lapland. Quaternary Science Reviews 14:799-809.

Smirnova E, Bergeron Y, Brais S. 2008. Influence of fire intensity on structure and composition of jack pine stands in the boreal forest of Quebec: live trees, understory vegetation and dead wood dynamics. Forest Ecology and Management 255:291627.

Splawinski TB, Cyr D, Gauthier S, Jetté JP, Bergeron Y. 2019. Analyzing risk of regeneration failure in the managed boreal forest of northwestern Quebec. Canadian Journal of Forest Research 49:680-91.

Stuiver M, Reimer PJ. 1993. Extended 14C data base and revised CALIB 3.0 14C age calibration program. Radiocarbon 35:21530.

Talon B, Carcaillet C. 2004. Wood anatomical criteria for identification of European Boreo-Alpine Ericaceae. International symposium of wood sciences, IAWA-IAWS, 24-29 October 2004, Montpellier, France.

Tweiten MA, Calcote RR, Lynch EA, Hotchkiss SC, Schuurman GW. 2015. Geophysical features influence the climate change sensitivity of northern Wisconsin pine and oak forests. Ecological Applications 25:1984-96.

Veillette JJ. 1994. Evolution and paleohydrology of glacial Lakes Barlow and Ojibway. Quaternary Science Reviews 13:945-71.

Viglas JN, Brown CD, Johnstone JF. 2013. Age and size effects on seed productivity of northern black spruce. Canadian Journal of Forest Research 43:534-43. 
Visnadi I, Housset J, Leroy C, Carcaillet C, Asselin H, Bergeron Y. 2019. Limited recruitment of eastern white cedar (Thuja occidentalis L.) under black spruce canopy at its northern distribution limit. Ecoscience 26:123-32.

Walker B, Holling CS, Carpenter SR, Kinzig A. 2004. Resilience, adaptability and transformability in social-ecological systems. Ecology and Society, 9:5. www.ecologyandsociety.org/vol9/ iss $2 / \operatorname{art} 5 /$.
Walker XJ, Baltzer JL, Cumming SG, Day NJ, Johnstone JL, Rogers BM, Mack MC, Mack MC. 2018. Soil organic layer combustion in boreal black spruce and jack pine stands of the Northwest Territories, Canada. International Journal of Wildland Fire 27:125-34.

Wardle D, Walker L, Bardgett R. 2004. Ecosystem properties and forest decline in contrasting long-term chronosequences. Science 305:509-13. 